\title{
Ethnobotany of babassu palm (Attalea speciosa Mart.) in the Tucurui Lake Protected Areas Mosaic - eastern Amazon
}

\author{
Fábio Ribeiro Araújo ${ }^{1 *}$, Sol Elizabeth González-Pérez², Maria Aparecida Lopes ${ }^{3}$ and Ismael de Jesus Matos Viégas ${ }^{4}$
}

Received: November 3, 2015

Accepted: March 7, 2016

\begin{abstract}
Documenting the ethnobotanical knowledge of populations living in protected areas is important both for science and for the effective conservation of these areas, as it can help to clarify the level of dependency that human communities have on local plant resources. Babassu (Attalea speciosa, Arecaceae) is one of the most important non-timber forest resources of rural communities in the Amazon. We explored the ethnobotanical knowledge and uses of babassu by riverine populations inhabiting the Tucuruí Lake Protected Areas Mosaic in the eastern Amazon, by examining the diversity, purposes and descriptions of its uses and aspects of its extraction. Data were collected in 2010 and 2014 from 193 families. A total of 1,226 use records were cited representing 60 different uses. Records were classified into nine use-categories; utensils and tools was the most important category, followed by construction and human food. The use with the greatest purpose consensus value among the informants was thatch. Babassu proved to be an important resource for the livelihood of the local communities in providing shelter, food and reliable energy. Most informants lacked knowledge about sustainable practices and management of this resource.
\end{abstract}

Keywords: local knowledge, non-timber forest resources, palm uses, riverine community, Tocantins river

\section{Introduction}

Considering the human populations living within or near conservation areas, local ecological knowledge can be of great value in management proposals based on the principles of local participation and sustainability (Sillitoe 1998; Huntington 2000). Ethnobotanical information can clarify the level of dependency of a community in relation to local plant resources, and provide information about the consequences of certain types of resource exploitation (Phillips 1996).

Palm trees of the family Arecaceae are one of the major non-timber forest resources for local populations. Their importance to local communities has been demonstrated in numerous studies in the Neotropics (Rocha \& Silva 2005; Albán et al. 2008; Nascimento 2010; Araújo \& Lopes 2012). This plant family is possibly the most commonly used by Amerindians and rural populations in the Amazon (Plotkin \& Balick 1984; Borchsenius et al. 1998; Macía et al. 2011; Paniagua-Zambrana et al. 2015) and has a key role in the subsistence strategies of many communities (Anderson 1991; Byg \& Balslev 2004). Research on the local perception of the importance of palm trees is of great interest because it can support successful practices for the conservation of the biological environment (Byg \& Balslev 2001).

Socioeconomic factors affect the distribution of ethnobotanical knowledge of palms used by informants. Knowledge about these relationships has a practical

\footnotetext{
${ }^{1}$ Instituto de Estudos em Desenvolvimento Agrário e Regional, Universidade Federal do Sul e Sudeste do Pará, Avenida dos Ipês - Cidade Universitária s/n, 68507-765, Marabá, PA, Brazil

${ }^{2}$ Núcleo de Altos Estudos Amazônicos, Universidade Federal do Pará, Rua Augusto Corrêa, 01, 66075-110, Belém, PA, Brazil

${ }^{3}$ Instituto de Ciências Biológicas, Universidade Federal do Pará, Rua Augusto Corrêa, 01, 66075-110, Belém, PA, Brazil

${ }^{4}$ Universidade Federal Rural da Amazônia, Rua João Pessoa, 113, 68700-030, Capanema, PA, Brazil

* Corresponding author: fabioaraujo@unifesspa.edu.br
} 
importance for the sustainable use and conservation of forest biodiversity, because it clarifies which social groups depend most on these natural resources and also underscores the mechanisms that cause their exploitation (Byg \& Balslev 2004).

Among the species of the family, the babassu (Attalea speciosa) stands out as one of the most abundant palm trees in the Amazon. It is distributed widely in the southern part of the region, from the Atlantic Ocean to Bolivia (Balick $\&$ Pinheiro 2000), especially in the eastern part of the Amazon, in the transition zones between the rainforest biome and the semi-arid of northeastern Brazil (May et al. 1985; Meirelles 2004). It can occur in low densities, in mature forests, or in high densities, in large degraded areas where it is considered a pioneer and dominant species (Anderson et al. 1991). The fact that all palm parts are useful is what makes this such an important palm tree for the livelihood of many traditional communities (Lima et al. 2003; Campos et al. 2015). The leaves are used for thatch to support roof structures (Rezende et al. 2010), in various crafts and household items (Corrêa et al. 2010), walls of homes and animal facilities, and as a fertilizer (Nascimento et al. 2009). The fruits are used as food, raw material for cosmetics, drugs and as a fuel source (Lima et al. 2003).

Given the importance of the family, it is vital, from a scientific point of view as well as an economic and conservationist one, to learn more about the local needs which are being met by palm products, how these are used, which social groups are more dependent on palm resources, or how palms are extracted (Rufino et al. 2008).

This study aims to explore the ethnobotanical knowledge of the babassu, by characterizing its uses regarding diversity and purpose, describing the forms of use and exploitation, and evaluating how socioeconomic factors affect the distribution of knowledge in riverine populations inhabiting the Tucuruí Lake Protected Areas Mosaic - eastern Amazon.

We expect, as a result of this study, that most of the uses will be concentrated and more diverse in the categories of utensils and tools and construction, with most intense use of leaves and seeds, respectively. In addition, we predict that the knowledge of babassu use will be more influenced by the economic activity of the informants.

\section{Materials and Methods}

\section{Study area}

The Tucuruí hydroelectric station is located on the Tocantins River in Pará state, eastern Brazilian Amazonia. The river was dammed in 1985 and about $2875 \mathrm{~km}^{2}$ of forest was flooded, causing changes in regional ecosystems and landscapes, including the formation of the actual reservoir and various islands made from higher non-flooded ground.

Since 1984, several Protected Areas have been created by the state government in the area of influence of the reservoir, composing in 2002 the Lake Tucuruí Protected Areas Mosaic (PAM) (Jatobá 2006). The PAM includes areas with different levels of protection of the biota: an Environmental Protection Area (EPA) and two Sustainable Development Reserves (SDR), where sustainable resource use is encouraged, and two zones of Wildlife Conservation (ZWC), which are strictly Protected Areas (Fig. 1). The original vegetation in the Lake Tucuruí PAM was predominantly open rainforest, however, even before the river was dammed, several areas of human influence already existed, which included fallow fields (secondary forest), cultivation, bare soil and pastures (Ohashi et al. 2004).

The region is occupied by groups of riverine populations, which may be dispersed or in communities, and rural properties of various sizes along the extension of the EPA (Araújo 2009). The population is estimated to be approximately 6,500 inhabitants, with two regions with the highest concentration of occupation of the islands: SDR Alcobaça (2,677 inhabitants) e SDR Pucuruí-Ararão (1,389 inhabitants) (SECTAM 2002). The activities performed by these populations are directly related to subsistence activities such as extraction of natural resources, agriculture and fishing (Jatobá 2006). Most of the residents do not have any formal education and do not benefit from essential public services such as water supply and drainage or universal services such as electricity, education and health (Ravena et al. 2009).

\section{Ethnobotanical data and Socio-economic variables}

We based the study on interviews that were made with household heads who were present in their homes throughout the study in an accidental manner (Albuquerque et al. 2008). The interviews were conducted from February to March 2010 and in June 2014, with 193 families that inhabit the Tucuruí Lake Protected Areas Mosaic. In 2010, 37 interviews were lost in a boat accident on the lake, which were only restored in 2014 after again interviewing the same household heads for which the information had been lost.

We tried to distribute the interviews along the whole reservoir and on both banks, and included all types of Protected Areas, particularly those that allow the use of natural resources (SDR and EPA). The research was authorized by the relevant government agencies (Environmental Department of the state of Pará, authorization n. 018/2009) and all respondents agreed to participate in the study after being informed of its goal.

The questionnaire consisted of semi-structured interviews about the knowledge and use of babassu with an introductory part containing the informant's personal data and socioeconomic characteristics (gender, age, federal state of birth, productive activity), and another part with questions related to aspects of the knowledge and use of palms in the study area (number of known uses, use purpose, plant parts used and form of exploitation). 
Ethnobotany of babassu palm [Attalea speciosa Mart.] in the

Tucurui Lake Protected Areas Mosaic - eastern Amazon...

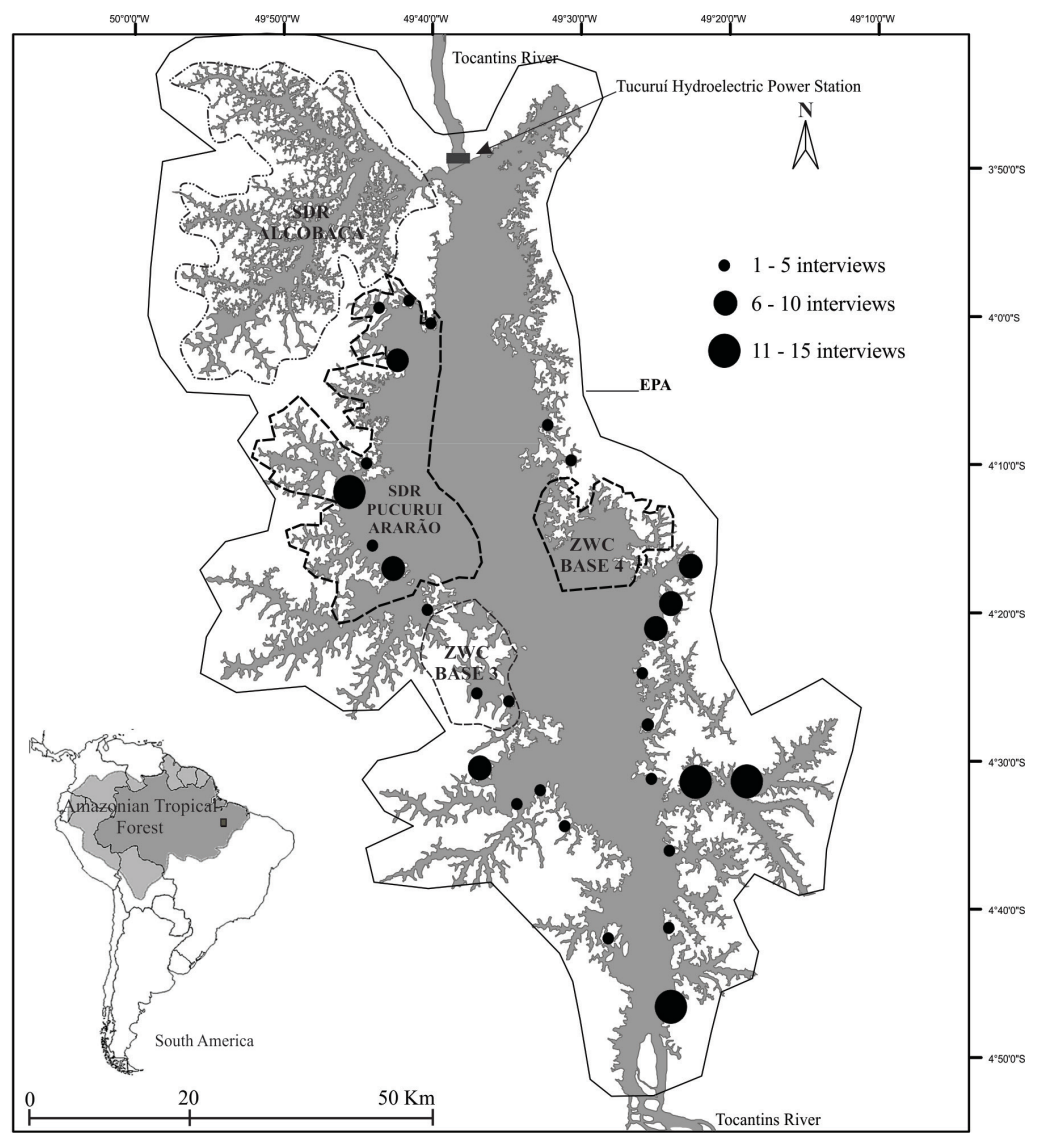

Figure 1. Map showing the location and boundaries of the Tucuruí Lake Protected Areas Mosaic. Black dots indicate locations where interviews were conducted and the number of interviews in each; EPA - Environmental Protection Area; SDR - Sustainable Development Reserve; ZWC - Zone of Wildlife Conservation.

The species was photographed and identified in the field by consulting the specialized literature (Henderson 1995; Lorenzi et al. 2010) and later confirmed by experts of the graduate course in Botany at the Federal Rural University of Amazonia and Herbarium João Murça Pires of the Museu Paraense Emílio Goeldi (MG), Belém, Pará (Fig. 2).

\section{Data analyses}

Uses reported by informants were classified into use categories and subcategories according to Macía et al. (2011) that in a review article on the use of palm trees on the western portion of South America, classified the ethnobotanical uses in ten categories each divided into subcategories, with ethnobotanical information unclassified in previous subcategories inserted into 'other'.

To determine how the species is used and which aspects of use contributes to importance according to informants of the Tucuruí Lake PAM we calculated the Use-diversity Value (UDV) index, that measures the importance of an use category and how each category contributes to the total use value, obtained from the number of recorded indications for a category divided by the total number of indications for all categories; Purpose Consensus Value (PCs) which measures the degree of agreement among informants concerning the use purpose, both based on Byg \& Balslev (2001), and Useful Plant Part Values (PPV) index, indicating which plant parts are more intensively used, obtained from the total number of citations reported for each part of the plant divided by the total number of citations for all plant parts, according to Gomez-Beloz (2002).

We used the Kolmogorov-Smirnov test to assess normality of distribution of knowledge of the babassu among the informants, and we conducted multiple regressions to evaluate the effect of socioeconomic factors on the knowledge of the use of the babassu as cited by the informants. In the regressions, we considered the socioeconomic data as independent variables and the measures of knowledge as dependent variables. We also performed a nonparametric test (Kruskal-Wallis) between the socioeconomic variables that showed greater effect on the knowledge in the regressions, to specify the socioeconomic variable that most influences the accumulation of knowledge of palms, from the comparison of sample means using Dunn's method. All tests were performed in BioEstat 5.3 software. 
Fábio Ribeiro Araújo, Sol Elizabeth González-Pérez,

Maria Aparecida Lopes and Ismael de Jesus Matos Viégas

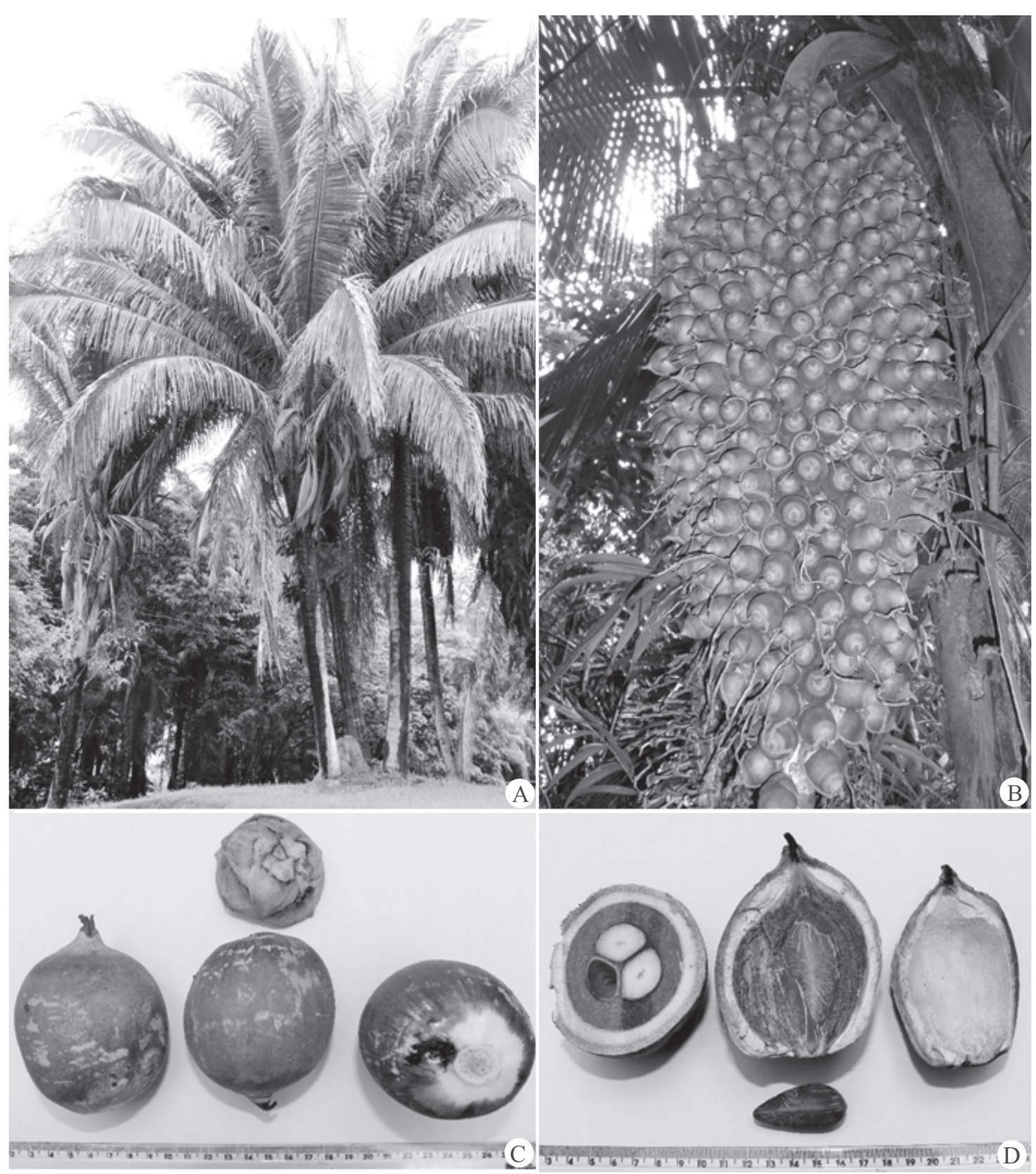

Figure 2. Photographic documentation of the species in the field. A) babassu palm; B) cluster of babassu palms; C) external aspect of the babassu fruit; D) internal aspect of the babassu fruit.

\section{Results and discussion}

\section{Socioeconomic aspects of the informants}

The set of informants included 77 women and 116 men and the age varied between 17 and 79 years, the majority varying from 26 to 55 years. In most families, fishing is the only productive activity (66\%), but some families combine fishing and agriculture (25\%) and others practice only agriculture (9\%). The origin of the interviewees is diverse:
45\% are from the state of Pará, $44 \%$ from the Brazilian northeast region, especially from the neighboring Maranhão state, and $11 \%$ from other parts of the country. A total of $75 \%$ of the interviewees have been living in the study area from six to 25 years, $16 \%$ from one to five years, and $9 \%$ have been living on the margins of the Tocantins River from 26 to 55 years. Ravena et al. (2009) and Piratoba (2014) recorded intense social mobility in the community at Lake Tucuruí PAM, resulting in a population that has been formed only recently, with fishing as the main current economic attraction. 


\section{Ethnobotany of babassu palm [Attalea speciosa Mart.) in the Tucurui Lake Protected Areas Mosaic - eastern Amazon...}

\section{Diversity of babassu use}

We recorded 1,226 citations about the use of babassu, grouped into 60 different uses, which were classified into nine use categories: utensils and tools, environmental uses, construction, human food, animal food, fuel, medicinal, cultural uses and other uses (Tab.1). Other studies in different regions of the Amazon attest to the use of this palm tree in these categories, such as Arruda et al. (2014) in quilombos, González-Pérez et al. (2012) in the Terra Indígena Las Casas Mebêngôkre-Kayapó in the southwest and southeast of the Brazilian Amazon, respectively, and
Paniagua-Zambrana (2005) in the Madidi region in Bolivia.

The most prominent use categories were utensils and tools, evidenced by the higher UDV, followed by construction and human food (Tab. 2). Campos et al. (2015), while studying the babassu oil extractive communities in northeastern Brazil, also registered the highest UDV in all three categories in the same order of importance presented here, however, the uses that we classified as utensils and tools were presented as handicrafts in Campos et al. (2015).

All respondents knew and used the species with an average of six listed uses, ranging from one to 19 uses. The most important use indicated by the degree of agreement

Table 1. Types of babassu uses classified into nine categories of use indicating the subcategory of use, plant part used, the number of citations for each different use, in descending order of the number of citations per category.

\begin{tabular}{|c|c|c|c|c|}
\hline Use category & Use subcategory & Types of babassu uses & Plant Part & Number of citations \\
\hline \multirow{15}{*}{ Utensils and Tools } & \multirow{8}{*}{ Domestic Utensils } & Basket & Leaves & 98 \\
\hline & & Fans & Leaves & 95 \\
\hline & & Mats & Leaves & 53 \\
\hline & & Sieves & Leaves & 16 \\
\hline & & Broom & Leaves & 8 \\
\hline & & Hamper & Leaves & 2 \\
\hline & & Feeder to animals & Spathe & 2 \\
\hline & & Shelf & Stem & 1 \\
\hline & \multirow{2}{*}{ Hunting and Fishing Tools } & Matapi (trap for shrimp) & Leaves & 57 \\
\hline & & Camaroeira (nurseries for shrimp) & Leaves & 27 \\
\hline & \multirow{4}{*}{ Wrappers } & Bowl to food & Spathe & 1 \\
\hline & & Insect repellent & Fruit (endocarp) & 30 \\
\hline & & Soap & Fruit (seed oil) & 26 \\
\hline & & Nests of domestic birds & Leaves & 19 \\
\hline & Other & Birdcage & Leaves & 1 \\
\hline Environmental Uses & Soil Improvers & Organic fertilizer & Stem & 11 \\
\hline \multirow{9}{*}{ Construction } & \multirow{4}{*}{ Houses } & Walls & Leaves & 85 \\
\hline & & Walls & Stem & 36 \\
\hline & & Wall for animal installations & Stem & 7 \\
\hline & & Floor & Stem & 2 \\
\hline & \multirow{3}{*}{ Thatch } & Thatched roof & Leaves & 165 \\
\hline & & Ridge & Leaves & 1 \\
\hline & & Roof to henhouse & Leaves & 1 \\
\hline & \multirow{2}{*}{ Other } & Palisade wall & Leaves & 16 \\
\hline & & Washbasin & Leaves & 1 \\
\hline \multirow{8}{*}{ Human Food } & Oil & Oil & Fruit (seed) & 118 \\
\hline & \multirow{7}{*}{ Food } & Coconut milk & Fruit (seed) & 111 \\
\hline & & Coconut in natura & Fruit (seed) & 18 \\
\hline & & Heart of palm & Meristem & 16 \\
\hline & & Mesocarp triturated in milk & Fruit (mesocarp) & 12 \\
\hline & & Porridge & Fruit (mesocarp) & 4 \\
\hline & & Coconut candy & Fruit (seed) & 3 \\
\hline & & Seed bagasse for beiju & Fruit (seed) & 1 \\
\hline \multirow{2}{*}{ Animal Food } & Fodder & Feed for animals & Fruit (seed) & 2 \\
\hline & Fish Bait & Bait shrimp & Fruit (seed) & 1 \\
\hline Fuel & Firewood & Cooking food & Fruit (endocarp) & 93 \\
\hline
\end{tabular}


Fábio Ribeiro Araújo, Sol Elizabeth González-Pérez,

Maria Aparecida Lopes and Ismael de Jesus Matos Viégas

Table 1. Cont.

\begin{tabular}{|c|c|c|c|c|}
\hline Use category & Use subcategory & Types of babassu uses & Plant Part & Number of citations \\
\hline \multirow{12}{*}{ Medicinal } & $\begin{array}{l}\text { Blood and } \\
\text { Cardio-vascular System }\end{array}$ & $\begin{array}{c}\text { Blood coagulation } \\
\text { Hemorrhoids }\end{array}$ & $\begin{array}{c}\text { Leaves } \\
\text { Fruit (seed oil) }\end{array}$ & $\begin{array}{c}19 \\
5\end{array}$ \\
\hline & Dental Health & Toothache & Fruit (endocarp) & 24 \\
\hline & \multirow{3}{*}{ Digestive System } & Gastritis & Fruit (mesocarp) & 6 \\
\hline & & Laxative & Fruit (seed oil) & 5 \\
\hline & & Hepatitis & Fruit (mesocarp) & 1 \\
\hline & $\begin{array}{l}\text { Infections and } \\
\text { Infestations }\end{array}$ & Vermifuge & Fruit (seed oil) & 3 \\
\hline & $\begin{array}{l}\text { Muscular-Skeletal } \\
\text { System }\end{array}$ & Osteoporosis & Fruit (mesocarp) & 1 \\
\hline & Poisoning & Bite of spiders & Fruit (seed) & 1 \\
\hline & $\begin{array}{l}\text { Reproductive System } \\
\text { and Reproductive } \\
\text { Health }\end{array}$ & Female genital inflammation & Fruit (seed oil) & 1 \\
\hline & Sensory System & Eye infection & Fruit (liquid albumen) & 1 \\
\hline & $\begin{array}{l}\text { Skin and Subcutaneous } \\
\text { Tissue }\end{array}$ & $\begin{array}{c}\text { Myiasis } \\
\text { Skin infection } \\
\text { Mycosis }\end{array}$ & $\begin{array}{l}\text { Fruit (seed oil) } \\
\text { Fruit (seed oil) } \\
\text { Fruit (seed oil) }\end{array}$ & $\begin{array}{l}2 \\
2 \\
1\end{array}$ \\
\hline & Not Specified & $\begin{array}{c}\text { Analgesic } \\
\text { Anti-inflammatory } \\
\text { Anti-inflammatory } \\
\text { Antithermic }\end{array}$ & $\begin{array}{c}\text { Fruit (endocarp) } \\
\text { Fruit (endocarp) } \\
\text { Fruit (seed oil) } \\
\text { Fruit (endocarp) }\end{array}$ & $\begin{array}{l}1 \\
1 \\
1 \\
1\end{array}$ \\
\hline Cultural Uses & Cosmetics & Hair moisturizing & Fruit (seed oil) & 1 \\
\hline Other Uses & Miscellaneous & $\begin{array}{l}\text { Sale } \\
\text { Beetle larvae* } \\
\text { Earache } \\
\text { Bait for fish } \\
\text { Hair moisturizing }\end{array}$ & $\begin{array}{l}\text { Fruit (seed oil) } \\
\text { Larva* } \\
\text { Oil of larva* } \\
\text { Larvae of beetle* } \\
\text { Oil of larva* }\end{array}$ & $\begin{array}{l}4 \\
2 \\
1 \\
1 \\
1\end{array}$ \\
\hline
\end{tabular}

* Larva of the beetle Pachymerus nucleorum which develops inside the seed of the coconut.

Table 2. Use-diversity values (UDV) for use categories of babassu indicated by informants of the Tucuruí Lake PAM.

\begin{tabular}{|l|c|c|}
\hline Categories & $\mathbf{N}^{\circ}$ different uses & UDV \\
\hline Utensils and tools & 15 & 0.126 \\
\hline Construction & 9 & 0.066 \\
\hline Human Food & 8 & 0.053 \\
\hline Fuel & 1 & 0.006 \\
\hline Medicinal & 18 & 0.004 \\
\hline Environmental uses & 1 & 0.001 \\
\hline Other Use & 5 & 0.001 \\
\hline Animal food & 2 & 0.001 \\
\hline Cultural Use & 1 & 0.001 \\
\hline
\end{tabular}

among respondents on the use purpose is thatch, which obtained the highest PCs (Tab. 3). Campos et al. (2015) recorded thatch as the most common use in two rural communities of babassu extrativists in northeastern Brazil.
Table 3. Purpose consensus value (PCs) for the ten main babassu uses determined by informants of the Tucuruí Lake PAM.

\begin{tabular}{|l|c|}
\hline Use & PCs \\
\hline Thatch & 0.0181 \\
\hline Oil & 0.0093 \\
\hline Coconut milk & 0.0082 \\
\hline Basket & 0.0064 \\
\hline Fans & 0.0060 \\
\hline Cooking food & 0.0058 \\
\hline Walls & 0.0048 \\
\hline Matapi (trap for shrimp) & 0.0022 \\
\hline Mats & 0.0019 \\
\hline Walls & 0.0009 \\
\hline
\end{tabular}

\section{Utensils and tools}

The category with the most use citations was utensils and tools (436), and leaves were the main part of the plant 
used, corresponding to $86 \%$ of the citations. Leaves are used to make baskets with different shapes and purposes, such as for transporting products collected in the forest, produced on the farm and fished, or to store food. They are also used for making bird nests, fans, sieves and mats, which often replace mattresses.

Babassu utensils are also important in fishing, the main economic activity of the riverine community in the Tucuruí Lake Protected Areas Mosaic. Ninety-four percent of respondents subsist from fishing, either exclusively or in combination with other activities. Fishing for Amazonian shrimp (Macrobrachium amazonicum) is an important activity for the economy and livelihood of the inhabitants of the Tucuruí Lake PAM. The capture is performed with a trap, called 'matapi', made from the babassu petiole. It has a cylindrical shape closed at the ends with cones. After capturing the shrimps, these are deposited in nurseries, called 'camaroeiras', made from the same material as the matapi.

Araújo et al. (2014), while researching fishing and shrimp capture procedures in the Amazon downstream from the Tucuruí hydroelectric station, demonstrated that the matapi stands out as the main utensil used: of 126 respondents, $72 \%$ reported using only the matapi for shrimp capture.

\section{Construction}

The most common use in this category is thatched roof. Eighty-five percent of respondents live in houses with roofs made from babassu leaves, $37 \%$ in homes with walls made of leaves and $15 \%$ in mud houses with internal structures made of slats taken from the stem.

In the Brazilian Amazon, babassu has been pointed out by several studies as the main building resource for traditional populations and forest dwellers and for rural communities. In the eastern part of the biome, these include indigenous communities such as the Apinajé and Guajajara (Balick 1988), the Guajá (Forline 2000), the Xicrin (Fuerst 2006), the Mebêngôkre-Kayapó (González-Pérez et al. 2012), the Krahò (Nascimento et al. 2009), and non-indigenous rural populations, such as the coconut-breaking women from Maranhão (Shiraishi 1999). Other examples include the Saterê-Mawé (Coelho-Ferreira 1994) in the west and the quilombo communities of Mato Grosso do Sul (Arruda et al. 2014).

For legal, economic and cultural reasons, babassu is the primary building resource of the inhabitants of the Tucuruí Lake PAM. Logging is illegal in almost all of the Protected Areas of the Tucuruí Lake Protected Areas Mosaic (Pará 2002). Logging is costly and demands a minimal infrastructure, including equipment, such as chainsaws, and fuel consumption. On the other hand, the absence of specific legal restrictions and inspection of the exploration of babassu in the Tucuruí Lake PAM is possibly another factor that influences the choice of this palm as the main construction resource by the inhabitants. Most of the population (44\%) comes from the Brazilian northeast, especially from the states of Maranhão and Piauí, where there are oligarchic formations of this palm tree, strongly linked to the livelihood and culture of the people (Barbieri 2004).

\section{Human Food}

The fruit is the main part of the palm used for food, and oil is the main product derived from the seed, with $50.8 \%$ of the respondents confirming its everyday use in cooking. Babassu is widely used in the Amazon and northeastern Brazil for this purpose and is considered the world's leading source of wild oil for domestic use (Lorenzi et al. 1996).

All respondents attest that the fruit collection is independent of gender, while oil extraction is carried out almost exclusively by women. This division of labor is repeated in other cultures in the Amazon (Shiraishi 1999; González-Pérez et al. 2012; Arruda et al. 2014). The seed is also consumed when processed with water. The mixture, called 'coconut milk', is used in the preparation of cooked meals, mainly fish, with $47.8 \%$ of respondents stating that this is part of their weekly meals. Other uses of the seed are less frequent, such as its direct raw consumption or when it is crushed to prepare confections, such as coconut candy.

The dry mesocarp is ground and sieved, originating the "babassu powder" that is mixed with milk as a drink or used as a substitute for wheat flour in the formulation of cakes and porridge. Another type of food use cited is the consumption of the apical meristem, called the palm heart. This form of consumption, common in the Amazon and in the northeast (Posey 1987; Rufino et al. 2008), involves the death of the plant. However, respondents claim that the palm trees are not felled for this purpose, and the use of meristem for food occurs when the palm is felled for other purposes, such as using the stem for buildings. They also state that the consumption of palm heart is sporadic and its frequency has diminished, because its extraction is a very labor intensive activity. This decrease was also recorded in quilombo communities of Mato Grosso (Arruda et al. 2014).

\section{Fuel}

The charcoal made from woody babassu endocarp is the only source of fuel for $40 \%$ of informants. Mainly used for cooking food, it helps to reduce excessive gathering of wood for these purposes in the forests of the Tucuruí Lake PAM. Several studies attest to the use of this important energy source by rural communities in the regions in which it occurs (May et al. 1985; González-Pérez et al. 2012; Rufino et al. 2008; Arruda et al. 2014). According to Albiero et al. (2007), babassu coal is the only source of fuel in various regions of northeastern Brazil.

The quality of babassu coal, added to the high price of 
coal from the wood of plants, and legal restrictions on the use of the latter, attracted the interest of steel companies based in southeastern Brazilian Amazonia who used babassu coal instead of coal from native trees. Between 1999 and 2007 the marketing of babassu coal for the steel industry was a supplementary income generating activity for approximately $33 \%$ of the informants.

\section{Medicinal}

The largest number of different uses was cited in the medicinal category; altogether 18 different uses with 76 citations. The use of babassu in folk medicine has been recorded by numerous studies that have indicated the use of many products derived from this plant by various local populations (Plotkin \& Balick 1984; Forline 2000; López et al. 2011; Sousa et al. 2011; Arruda et al. 2014). In addition, several studies of preclinical analysis contributed to the validation of this knowledge, attesting its anti-inflammatory action (Silva \& Parente 2001), immunomodulatory action (Nascimento et al. 2006), antitumor activity (Fortes et al. 2009; Souza et al. 2011), and its use for stimulating the production of lymphocytes (Barroqueiro 2001) as well as its analgesic effect (Pinheiro et al. 2012).

The fruit was the most important plant part for medicinal purposes, resin endocarp being its main byproduct with the highest number of citations (27) being the relief of toothache its most quoted use. The ingestion of the triturated mesocarp, dried and mixed with water, was cited in combating gastritis, hepatitis and osteoporosis, and in the form of a poultice in cases of mycosis. Sousa et al. (2011) also reported the use of mesocarp powder for various therapeutic purposes in six rural communities of coconut breakers in Maranhão. The main uses were to treat gastritis, general inflammation and leukorrhea. Studies have demonstrated the effectiveness of the aqueous layer of babassu mesocarp for gastric (Batista et al. 2006) and skin healing (Maciel et al. 2007), supporting their therapeutic use.

The oil extracted from the seed is used after being refined as well as the residue called 'borra' which, according to respondents, is stronger and toxic. The refined form is used in the treatment of hemorrhoids, skin infections and as a general anti-inflammatory drug, and the 'borra' is used as a laxative, worm medicine, and for combating myiasis and female genital inflammation, such as leukorrhea. Sousa et al. (2011) reported the use of oil and 'borra' in the treatment of female genital tract inflammations and various skin infections. Balick (1984) also reported the use of oil as worm medicine and as an expectorant by traditional communities in Bolivia.

The liquid albumen, taken from the immature fruit, was quoted as being used to treat eye infections and the juice of the unripe petiole had the second highest use citation in the medicinal category, being used to stop hemorrhages. The seed bagasse is also used for spider bites, with direct application to the bite site.

\section{Animal Food, Cultural and Environmental Use}

Babassu is also used as animal food, for which the only use cited is feeding domestic birds. Its use to attract the shrimp into the matapi was also recorded - for this, babassu seed crumbs are used, wrapped in cupuassu (Theobroma grandiflorum), cacao (Theobroma cacao) or banana (Musa sp.) leaves.

Regarding the cultural use of babassu by the riverine communities, the removal of babassu oil from the fruit is cited for hair moisturizing purposes. Babassu oil is applied directly to the hair. González-Pérez et al. (2012) show that for the Kayapó indigenous people the most cited use of babassu oil is as a cosmetic; the Kayapós spread it over the skin so that it becomes "beautiful and fragrant."

Referring to environmental use, after decomposition on the forest floor the stipe is used as an organic fertilizer called "paû" that is mixed with the soil of small vegetable grown for family consumption. The practice is not widespread among the informants; only eleven citations of this use were recorded. This use was also recorded with few citations in studies in other parts of the country, such as in Campos et al. (2015) for extractive communities in the northeast and Nascimento et al. (2009) for indigenous people in the central region.

\section{Other uses}

The trade of babassu derivatives is insignificant in the Tucuruí Lake Protected Areas Mosaic, with the sporadic sale of babassu oil having only been reported for four families. The sale happens when there are opportunities to go to neighboring villages and towns and the amount traded is small; four to six liters are transported each time, generally once a month. This data is corroborated by Jatobá (2006), who reported that non-timber extraction is poorly practiced in the Tucuruí Lake PAM and is designed mainly for family consumption, being commercialized only sporadically. This shows that the palm has an almost exclusive subsistence role for the inhabitants of the surveyed area.

Indirect babassu uses also occur, such as the use of larvae of the beetle Pachymerus nucleorum that develops inside the fruit, instead of the seed. It can be used directly in human food or used as bait for fish, and the oil removed from the larvae by heating has medicinal (analgesic for earaches) and aesthetic (capillary moisture) uses.

\section{Resources extraction and management}

In the Tucurui Lake PAM, the plant parts most intensively used are the fruits and leaves, evidenced by the higher PPV values (Tab. 4). Other studies on babassu use in 
Table 4. Useful Plant Part Values (PPV) for babassu determined by the uses of the inhabitants of the Tucuruí Lake PAM.

\begin{tabular}{|l|l|}
\hline Plant part & PPV \\
\hline Fruit & 0.554 \\
\hline Leaves & 0.304 \\
\hline Stipe & 0.089 \\
\hline Spata & 0.036 \\
\hline Meristem & 0.018 \\
\hline
\end{tabular}

Brazil also recorded a use concentration in fruits and leaves showing a high PPV, in western quilombos (Martins et al. 2014); an indigenous group in the north (González-Pérez et al. 2012) and extractivist communities in the northeast (Campos et al. 2015).

Eighty-two percent of the informants state that extraction does not meet management criteria, and all claim to be unaware of technical guidelines for good nontimber forest management practices for the species, such as how many and which leaves should be removed per plant, the minimum number of palm trees that should remain per hectare or how much fruit should be left in the forest for recruitment of the species.

Construction is probably the use category that most increases the exploration pressure on the species in the study area, and thatch is the category with most intensive use, as already described, with widespread use and the highest PCs value among the informants. In the study area, each family uses 200-350 babassu leaves per thatch, which are replaced every two or three years, creating a continuous demand. The leaves are removed from both mature and juvenile palms.

According to the respondents, in regions where the occurrence of the plant is low and there are large individuals, it is common to overthrow the whole plant in order to make complete use of the leaves. The respondents claim that the resource is scarce or non-existent in many parts of the study area; 31 of these, all residents of the SDR Pucuruí-Ararão stated that they traveled up to $25 \mathrm{~km}$ in boats in search of babassu elsewhere.

The information that the distribution of babassu is not uniform across the Tucuruí Lake Protected Areas Mosaic is supported by Kahn (1986), who carried out inventories of palm trees in eight forest areas spread over $200 \mathrm{~km}$ on both banks of the Tocantins River, in areas currently submerged by the reservoir. The species was recorded in three of the eight surveyed areas, all in the southern part of the study area, more concentrated on the left bank (upstream to downstream direction).

\section{Distribution of knowledge among the informants}

The distribution of knowledge about babassu, in terms of number of uses known by the informants, showed a non-normal distribution (Kolmogorov - Smirnov d: 0.172, $\mathrm{p}<0.01$ ), which indicates that knowledge of palms is not homogeneously distributed among the residents of the study area, where most of the respondents know a higher or lower number than the average listed uses.

Socioeconomic factors that most influence the knowledge of babassu were gender and economic activity of the responders. Other factors also contributed but with lower significance, such as the amount of time living in the study area and age of the informant (Tab. 5).

The time living in the study area and the age of the informant were directly related with the knowledge of babassu, indicating that older informants know more uses than young residents. This difference may be related to the gradual accumulation of knowledge throughout life and the erosion of knowledge (Phillips \& Gentry 1993).

Table 5. Relationship between knowledge of the informants (Number of known uses, number of uses per category) and the socioeconomic characteristics of the informants. We included in the table only results that were statistically significant.

\begin{tabular}{|c|c|c|c|c|c|c|c|}
\hline & Gender & Age & Time & Origin & Activity & $\mathbf{P}$ & $\mathbf{R}^{2}$ \\
\hline Number of known uses & $-* * *$ & & & & $+t^{* * * *}$ & $<0.0001$ & 0.1664 \\
\hline \multicolumn{8}{|c|}{ Number of uses $p /$ category } \\
\hline Utensils and tools & & & & & $+^{* * * *}$ & 0.0124 & 0.0356 \\
\hline Construction & $+^{* *}$ & & $+^{*}$ & & $+^{* * * *}$ & $<0.0001$ & 0.1081 \\
\hline Human Food & $-* *$ & & & & $+* * * *$ & $<0.0001$ & 0.2562 \\
\hline Fuel & $+^{*}$ & $+^{*}$ & & & & 0.0015 & 0.0583 \\
\hline Medicinal & $-* * * *$ & & & & $+^{*}$ & $<0.0001$ & 0.4684 \\
\hline Environmental uses & & & & & & 0.5424 & 0.0078 \\
\hline Cultural Use & $-* *$ & & $+^{* *}$ & & & 0.5555 & 0.0063 \\
\hline Animal food & & & & & $+^{* * *}$ & $<0.0001$ & 0.1559 \\
\hline Other Use & & & & & & 0.6475 & 0.0125 \\
\hline
\end{tabular}

+: Positive correlation, -: negative correlation; significance levels: ${ }^{*} 0.01<\mathrm{P} \leq 0.05,{ }^{* *} 0.001<\mathrm{P} \leq 0.01,{ }^{* * *} 0.0001<\mathrm{P} \leq 0.001$, **** $\mathrm{P} \leq 0.0001$ 
The economic activity of the informant was also the main factor of influence in all categories of use, particularly in utensils and tools and human food (Tab. 5). Farmers showed greater means related to number of uses known than fishermen (Fig. 3). Byg \& Balslev (2001), in Madagascar, found a direct positive relationship between agricultural diversification and knowledge of use of palms and considered that this trend could be related to the direct action that the farmer has on the floristic environment.

Socioeconomic factors did not show a statistically significant influence on the categories: environmental uses, cultural uses and other uses (Tab. 5)

In a general manner, women know more about babassu uses than men; they particularly have greater medicinal knowledge about the species (Tab. 6). Differences in knowledge of men and women are related to differences in their areas of responsibilities and daily activities: women often know more uses related to medicinal and food categories, while men know more about construction and commercially valuable species (Hanazaki et al. 2000; Luoga et al. 2000; Byg \& Balslev 2004).

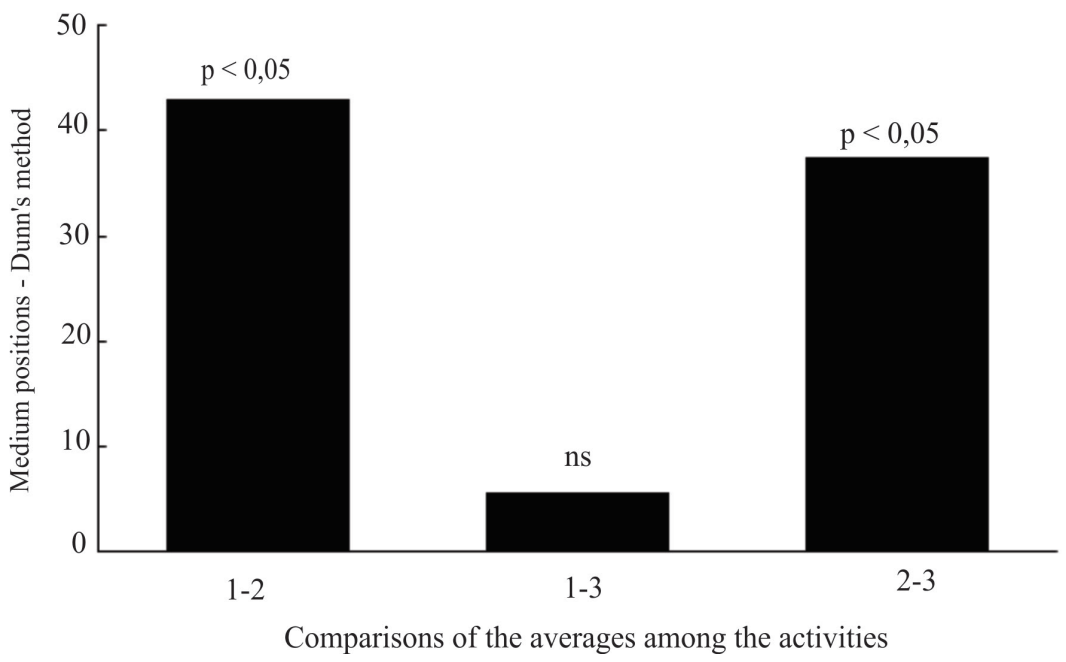

Figure 3. Comparison of the number of uses known per informant according to the economic activity (Kruskal-Wallis non-parametric tests) using Dunn's method for comparing means: 1 only agriculture, 2 only fishing, 3 agriculture and fishing; ns: not significant.

Table 6. Comparison of means related to knowledge of General use and Medicinal use of babassu between men and women (KruskalWallis test) using Dunn's method for comparison of means.

\begin{tabular}{|c|c|c|}
\hline Parameters & General use & Medicinal use \\
\hline$H=$ & 15.75 & 49.59 \\
\hline Degrees of freedom & 1 & 1 \\
\hline (P) & $<0.0001$ & $<0.0001$ \\
\hline Women [medium position] & 123.40 & 144.97 \\
\hline Men [medium position] & 86.58 & 79.69 \\
\hline Comparison [Dunn's method] & \multicolumn{2}{|c|}{ Difference of positions } \\
\hline Medium position men and women & 36.81 & 65.28 \\
\hline
\end{tabular}

\section{Conclusion}

The daily dependence that the inhabitants of the Tucurui Lake Protected Areas Mosaic have on this palm tree, mainly in the utensils and tools, for construction, human food and fuel, shows that babassu is an important resource for their livelihood strategies.

Although informants have shown strong sociocultural connection with the species, there is a lack of appropriate management of a more sustainable exploration by most of them.

Distribution surveys and current babassu abundance throughout the area should subsidize the exploitation strategies, because exploration that decimates the local population of babassu will put at risk the guarantee of shelter and food and energy security for much of the population. Instead, it will also encourage an increased exploitation pressure on timber forest resources. 


\section{Ethnobotany of babassu palm [Attalea speciosa Mart.) in the \\ Tucurui Lake Protected Areas Mosaic - eastern Amazon...}

The study of knowledge distribution patterns among the informants revealed the role of agriculture and the female gender as the main factors determining the detention of knowledge about the use of babassu.

\section{Acknowledgements}

We thank The Tucuruí PAM communities. The Federal Rural University of Amazonia, and CNPQ (Conselho Nacional de Desenvolvimento Científico e Tecnológico), Eletrobrás - Eletronorte SA. Antônio Elielson Sousa Rocha for confirmation of species identification. The sharing of the results of this research with local communities will be in the form of lectures where we will discuss the sustainable use of the resource and good use practices and management of babassu. Text and grammar Review by Magda Alves de Sousa Gobira.

\section{References}

Albiero D, Maciel J, López C, Mello C, Gamero CA. 2007. Proposta de uma máquina para colheita mecanizada de babaçu (Orbignya phalerata Mart.) para agricultura familiar nas regiões de matas de transição da Amazônia. Acta Amazonica 37: 337-346.

Albuquerque UP, Lucena RFP, Cunha LVFC. 2008. Métodos e técnicas na pesquisa etnobotânica. 2nd. edn. Recife, Comugraf.

Anderson AB. 1991. Forest management strategies by rural inhabitants in the Amazon estuary. In: Goméz-Pompa A, Whitmore TC, Hadley M. (eds.) Rain forest regeneration and management. Paris, United Nations Educational, Scientific and Cultural Organizations. p. 351-360.

Anderson AB, May P, Balick M. 1991. The subsidy from nature: Palm forests, peasantry, and development on an Amazon frontier. New York, Columbia University Press.

Araújo ARO. 2009. Os territórios protegidos e a Eletronorte na área de influência da UHE Tucuruí/PA. MSc Thesis, Universidade Federal do Pará, Brazil.

Araújo FR, Lopes MA. 2012. Diversity of use and local knowledge of palms (Arecaceae) in eastern Amazonia. Biodiversity and Conservation 21: 487-501.

Araújo MVLF, Silva KCA, Silva BB, Ferreira ILS, Cintra IHA. 2014. Pesca e procedimentos de captura do camarão-da-Amazônia à jusante de uma usina hidrelétrica na Amazônia brasileira. Biota Amazônia 4: 102-112.

Arruda JC, Sander NL, Silva CJ. 2014. Conhecimento e Uso do Babaçu (Attalea Speciosa Mart.) por Quilombolas em Mato Grosso. Fragmentos de Cultura 24: 239-252.

Balick MJ. 1984. Ethnobotany of palms in the Neotropics. Advances in Economic Botany 1: 9-23.

Balick MJ. 1988. The use of palms by the Apinajé and Guajará Indians of Northeastern Brazil. Advances in Economic Botany 6: 65-90.

Balick MJ, Pinheiro C. 2000. Babaçu Orbignya phalerata. In: Clay JSP, Clement C. (eds.) Biodiversidade Amazônica: Exemplos e Estratégias de Utilização. Óleos Industriais. Manaus, Instituto Nacional de Pesquisa da Amazônia, SEBRAE. p. 255-263.

Barbieri ALC. 2004. Desenvolvimento recente do Maranhão: uma análise do crescimento do PIB e expectativas. MSc Thesis, Universidade federal do Pernambuco, Brazil.

Barroqueiro ESB. 2001. Efeito do mesocarpo de babaçu sobre a produção de anticorpos auto-reativos. MSc Thesis, Universidade Federal do Maranhão, Brazil

Batista CP, Torres OJM, Matias JEF, et al. 2006. Effect of aqueous extract of Orbignya phalerata (babassu) in the gastric healing in rats: morphologic and tensiometric study. Acta Cirúrgica Brasileira 21: 26-31.
Borchsenius F, Borgtoft PH, Balslev H. 1998. Manual to the Palms of Ecuador. Aarhus, Denmark: Department of Systematic Botany, Aarhus University-Pontificia Universidad Católica del Ecuador, Quito. Association of American Universities Reports 37.

Byg A, Balslev H. 2001. Diversity and use of palms in Zahamena, eastern Madagascar. Biodiversity and Conservation 10: 951-970.

Byg A, Balslev H. 2004. Factors affecting local knowledge of palms in Nangaritza Valley in South-Eastern Ecuador. Journal of Etnhnobiology 24: 255-278.

Campos JLA, Silva TLL, Albuquerque UP, Peroni N, Araújo EL. 2015. Knowledge, Use, and Management of the Babassu Palm (Attalea speciosa Mart. ex Spreng) in the Araripe Region (Northeastern Brazil). Economic Botany 69: 240-250.

Coelho-Ferreira M. 1994. Essai sur l'ethnopharmacologie et la gestion des ressources naturelles chez les Saterê-Mawé du fleuve Marau, Moyen Amazonas, Brésil. Paris, Muséum National d'Histoire Naturel, Rapport de Mission.

Corrêa DAG, Ming LC, Vasques MP. 2010. Manejo de fibras vegetais utilizadas em artesanatos por comunidades tradicionais do parque estadual e turístico do Alto Ribeira, e seu entorno, Iporanga, SP. In: Silva VA, Almeida ALS, Albuquerque UP. (eds.) Etnobiologia e Etnoecologia: Pessoas \& natureza na América Latina. 1st. edn. Recife. Nupeea. p. 173-208.

Forline LC. 2000. Using and sustaining resources: the Guajá Indians and the babassu palm (Attalea speciosa). Indigenous Knowledge and Development Monitor 8: 3-7.

Fortes TS, Azevedo APS, Barroqueiro ES, et al. 2009. Desenvolvimento do Tumor de Ehrlich em Camundongos após incubação in vitro com mesocarpo de babaçu. Revista de Ciências da Saúde 11: 11-18.

Fuerst R. 2006. Xicrin hommes oiseaux d'Amazonie. Milan, 5 Continents Editions.

Gomez-Beloz A. 2002. Plant use knowledge of the Winikina Warao: the case for questionnaires in ethnobotany. Economic Botany 56: 231-241.

González-Pérez SE, Coelho-Ferreira M, Robert P, Garcés CLL. 2012. Conhecimento e usos do babaçu (Attalea speciosa Mart. e Attalea eichleri (Drude)) entre os Mebêngôkre-Kayapó da Terra Indígena Las Casas, estado do Pará, Brasil. Acta Botanica Brasilica 26: 295- 308.

Hanazaki N, Tamashiro JY, Leitão-Filho HF, Begossi A. 2000. Diversity of plant uses in two Caiçara communities form the Atlantic forest coast, Brazil. Biodiversity and Conservation 9: 597-615.

Henderson A .1995. The Palms of the Amazon. New York, Oxford University Press.

Huntington HP. 2000. Using traditional ecological knowledge in science: methods and applications. Ecological Applications 10: 1270-1274.

Jatobá SUS. 2006. Gestão do território e a produção da socionatureza nas ilhas do Lago de Tucuruí na Amazônia brasileira. MSc Thesis, Universidade de Brasília, Brazil.

Kahn F. 1986. Les palmiers des forêts tropicales humides du Bas Tocantins (Amazonie brésilienne). Revue d`Ecologie: La Terre et La Vie 41: 3-13.

Lima ES, Felfili JM, Marimon BS, Scariot A. 2003. Diversidade, estrutura e distribuição espacial de palmeiras em um cerrado sensu stricto no Brasil Central - DF. Revista Brasileira de Botânica 263: 361-370.

López C, Gonzalez-Pérez S, Coelho-Ferreira M, et al. 2011. Laboratório de práticas sustentáveis em Terras Indígenas próximas ao Arco de Desmatamento Terra Indígena Las Casas - PA/Terra Indígena KayapóMoikarakô e Terra Indígena Alto Turiaçu aldeias Xiepihu-rena e Paracuirena. Belém, INCT-MPEG - Relatório anual.

Lorenzi H. 1996. Palmeiras no Brasil nativas e exóticas. Nova Odessa, Editora Plantarum.

Lorenzi H, Kahn F, Noblick LR, Ferreira E. 2010. Flora Brasileira Lorenzi: Arecaceae (Palmeiras). Nova Odessa, Editora Plantarum.

Luoga EJ, Witkowski ETF, Balkwill K. 2000. Differential utilization and ethnobotany of trees in Kitulanghalo forest reserve and surrounding communal lands, eastern Tanzania. Economic Botany 54: 328-343.

Macía MJ, Armesilla PJ, Cámara-Leret R, et al. 2011. Palm Uses in Northwestern South America: A Quantitative Review. The Botanical Review 77: 462-570. 
Fábio Ribeiro Araújo, Sol Elizabeth González-Pérez,

Maria Aparecida Lopes and Ismael de Jesus Matos Viégas

Maciel MCG, Barroqueiro ESB, Silva LA, Guerra RNM, Nascimento FR. 2007. Avaliação do Efeito Cicatrizante do Mesocarpo de Babaçu (Orbignya phalerata) em Feridas de Pele Induzidas em Camundongos. Revista de Ciências da Saúde 9: 1-4.

Martins RC, Filgueiras TS, Albuquerque UP. 2014. Use and diversity of palm (Arecaceae) resources in central western Brazil. The Scientific World Journal 14: 1-14.

May PH, Anderson AB, Balick MJ, Frazão JM. 1985. Subsistence benefits from the Babassu palm (Orbignya martiana). Economic Botany 39: 113-129.

Meirelles JF. 2004. O Livro de Ouro da Amazônia: Mitos e verdades sobre a região mais cobiçada do planeta. 4th. edn. São Paulo, Ediouro.

Nascimento AR. 2010. Riqueza e etnobotânica de palmeiras no território indígena Krahô, Tocantins, Brasil. Floresta 40: 209-220.

Nascimento AR, Santos A, Martins R, Borges T. 2009. Comunidade de palmeiras no território indígena Krahò, Tocantins, Brasil: biodiversidade e aspectos etnobotânicos. Interciência 34: 182-184.

Nascimento FRF, Barroqueiro ESB, Azevedo APS, et al. 2006. Macrophage activation induced by Orbigna phalerata Mart. Journal of ethnopharmacology 103: 53-58.

Ohashi ST, Vieira ICG, Leão NVM. 2004. Fitossociologia e estrutura de uma floresta remanescente da área de soltura 4 da UHE - Tucuruí. Belém, Relatório Técnico Eletronorte.

Paniagua-Zambrana NY. 2005. Diversidad, densidad, distribución y uso de las palmas en la región del Madidi, noreste del departamento de La Paz (Bolivia). Ecología em Bolivia 40: 265-280.

Paniagua-Zambrana NY, Cámara-Leret R, Macía MJ. 2015. Patterns of medicinal use of palms across northwestern South America. The Botanical Review 81: 317-415.

Pará. 2002. Lei № 6.451, de 8 de abril de 2002. Cria Unidades de Conservação da Natureza na região do Lago de Tucuruí no território sob jurisdição do Estado do Pará. Belém, Assembléia Legislativa do Estado do Pará.

Phillips O, Gentry AH. 1993. The useful plants of Tambopata, Peru: II Additional hypothesis testing in quantitative ethnobotany. Economic Botany 47: 33-43.

Phillips O. 1996. Some quantitative methods for analyzing ethnobotanical knowledge. In: Alexiades M. (ed.) Selected guidelines for ethnobotanical research: a field manual. New York, New York Botanical Garden. p.171-197.
Pinheiro MMG, Boylan F, Fernandes PD. 2012. Antinociceptive effect of the Orbignya speciosa Mart. (Babassu) leaves: evidence for the involvement of apigenin. Life Sciences 91: 293-300.

Piratoba MD. 2014. Dinâmica Temporal da Paisagem: mudanças, percepções e dificuldades de recuperação na RDS Alcobaça, área de influência da UHE Tucuruí/PA. MSc Thesis, Universidade Federal do Pará, Brazil

Plotkin MJ, Balick MJ. 1984. Medicinal uses of South American palms. Journal of ethnopharmacology 10: 157-179.

Posey D. 1987. Manejo da floresta secundaria, capoeira, campos e cerrados (Kayapó). In: Ribeiro B. (ed.) Suma Etnológica Brasileira. Vol. 1. 2nd. edn. Petrópolis, Vozes. p. 173-185.

Ravena N, Cañete VR, Souza CL, Cañete TMR. 2009. Lições não aprendidas: Hidroelétricas, impactos ambientais e políticas de recursos hídricos. Paper NAEA 239.

Rezende JBA, Lima J, Meira FM, Lima P, Tenório G. 2010. Manejo de Caraná no Alto Tiquié. In: Cabalzar A. (ed.) Manejo do mundo: conhecimento e práticas dos povos indígenas do Rio Negro, noroeste Amazônico. São Paulo, FOIRN \& ISA.

Rocha AES, Silva MFF. 2005. Aspectos fitossociológicos, florísticos e etnobotânicos das palmeiras (Arecaceae) de floresta secundária no município de Bragança, PA, Brasil. Acta Botanica Brasilica 19: 657-667.

Rufino MUL, Costa JTM, Silva VA, Andrade LHC. 2008. Conhecimento e uso do Ouricuri (Syagrus coronata) e do babaçu (Orbignya phalerata) em Buíque, PE, Brasil. Acta Botanica Brasilica 22: 1141-1149.

SECTAM - Secretaria Executiva de Ciência, Tecnologia e Meio Ambiente do Estado do Pará. 2002. Levantamento Socioeconômico das Ilhas do Lago de Tucuruí. Belém, Governo do Estado do Pará.

Shiraishi NJ. 1999. As quebradeiras de coco no meio norte. Paper NAEA 121.

Sillitoe P. 1998. The development of indigenous knowledge. Current Anthropology 39: 223-252.

Silva BP, Parente JP. 2001. An anti-inflammatory and immunomodulatory polysaccharide from Orbignya phalerata. Fitoterapia 72: 887-93.

Sousa MHSL, Monteiro CA, Figueredo PMS, Nascimento FRF, Guerra RNM. 2011. Ethnopharmacological use of babassu (Orbignya phalerata Mart) in communities of babassu nut breakers in Maranhão, Brazil. Journal of Ethnopharmacology 133: 1-5.

Souza PAVR, Palumbo A, Alves LM, et al. 2011. Effects of a nanocomposite containing Orbignya speciosa lipophilic extract on Benign Prostatic Hyperplasia. Journal of ethnopharmacology 135: 135-146. 